\title{
Macronutrient contents in rose crops under salinity levels and nitrogen:potassium ratios
}

\author{
Everaldo Moreira da Silva ${ }^{1 *}$, Carlos José Gonçalves Souza Lima², Jarbas Honório de Miranda³, \\ Aureliano Albuquerque Ribeiro ${ }^{4}$, Sérgio Nascimento Duarte ${ }^{3}$
}

\author{
Federal University of Piaui, Bom Jesus, Pl,Brazil \\ ${ }^{2}$ Federal University of Piaui, Teresina, Pl, Brazil \\ ${ }^{3}$ Luiz de Queiroz College of Agriculture, Piracicaba, SP, Brazil \\ ${ }^{4}$ Federal University of Ceará, Fortaleza, CE, Brazil \\ *Corresponding author, e-mail: everaldo@ufpi.edu.br
}

Abstract

Rose crops under fertigation in a protected environment is an alternative for production increase. However, the high dosages of fertilizers can lead to the salinization of soils in this environment. The aim of this study was to evaluate the effect of salinity caused by the excess of fertilizer application through fertigation associated with different nitrogen: potassium ( $N$ : K) ratios on macronutrient contents in rose crops. The study was performed in a randomized block design, arranged in a factorial scheme $15 \times 3$ +1 ), with four repetitions, totaling 64 plots. The treatments were formed by combination of five initial levels of electrical conductivity (EC: 1.2; 2.3; 3.3; 4.3 e $5.5 \mathrm{dS} \mathrm{m}^{-1}$ ), three nitrogen: potassium (N: K) ratios $(2: 1 ; 1: 2$ and $1: 3)$ and a control with $\mathrm{N}$ : K ratio (1: 1). Contents of N, K, Ca, Mg and S were evaluated in the stem, leaves and flowers. The levels of $\mathrm{N}, \mathrm{K}, \mathrm{P}, \mathrm{Ca}$ and $\mathrm{Mg}$ in plant tissues are affected by the treatments at 245 days after transplanting. Leaves presented the highest levels of macronutrients, mainly nitrogen. TDR probe is a satisfactory tool in the management of fertigation.

Keywords: chemical fertilizers, electrical conductivity, Rosa SP

\section{Introduction}

Floriculture is an intensive agricultural activity which requires high investment in technology and technical training. However, there is still little information about fertigation management techniques, which would avoid the excessive application of fertilizers, reducing the risk of soil salinization and leading to the maximum productive potential of the agricultural activity.

The production of roses in a protected environment is larger than field cultivation, since it allows greater advantages to the producers (Oliveira et al., 2014) as protection of plants against climatic adversities, increased yield, increased efficiency of water and fertilizers use and products of high commercial quality (Dias et al., 2005).

However, inadequate irrigation management, the addition of fertilizers in high doses and the lack of rain, which promotes the leaching of excess salts applied through irrigation water, can lead to salinization of soils in protected environments (Dias et al., 2005 ).

Soil salinity, which can be derived from the misuse of highly soluble fertilizer salts and easily transported in water, is a precursor of severe damage to soil and plants (Medeiros et al., 2011). It promotes nutritional imbalance in plants due to the competition among salts and nutrients in the absorption process (Demiral, 2005) and reduction in transpiration, photosynthesis, translocation and respiration (Gomes et al., 2005).

Salinity caused by inadequate management of fertigation can be investigated with the use of several laboratory and field methodologies (Medeiros et al., 2010). Besides the use of soil solution extractors, the time domain reflectometry technique (TDR) has been recently used in field (Souza et al., 2006). This technique has been consolidating as an important tool for soil solution monitoring and its ionic composition 
(Souza \& Folegatti, 2010). Among the monitored ions, potassium (Santana et al., 2007) and nitrate (Santos et al., 2009) stand out.

Nitrogen and potassium are the most required nutrients by rose crops. Nitrogen is absorbed in greater amounts during the vegetative growth phase. Potassium is absorbed in greater quantity in the development phase of floral buds, providing size and coloration to petals (Casarini, 2004).

Thus, the aim of this study was to evaluate the effect of salinity caused by excess fertigation application associated with different nitrogen:potassium ( $\mathrm{N}: \mathrm{K}$ ) ratios on macronutrient contents in plant tissue of stems, leaves and buds of rose crops and to evaluate the use of time domain reflectometry (TDR) in the management of fertigation to control soil salinization.

\section{Materials and Methods}

The research was carried out in a protected environment in the Department of Biosystems Engineering, College of Agriculture "Luiz de Queiroz" - USP, in Piracicaba-SP, located at $22^{\circ} 42$ 'S and $47^{\circ} 38^{\prime} \mathrm{W}$ and altitude of $540 \mathrm{~m}$. The soil was collected from a profile classified as red-yellow latosol, sandy phase, obtained in the $0,30 \mathrm{~m}$ depth of the agriculturally layer (Table 1).

Table 1. Soil physical and chemical characterization.

\begin{tabular}{|c|c|c|c|c|c|c|c|c|c|c|c|c|c|}
\hline \multicolumn{2}{|c|}{ Granulometry (\%) } & \multicolumn{3}{|c|}{ Density $\left(\mathrm{g} \mathrm{cm}^{-3}\right)$} & \multicolumn{6}{|c|}{ Porosity (\%) } & \multirow{2}{*}{\multicolumn{3}{|c|}{$\begin{array}{l}\text { Textural Class } \\
\text { Frank Sandy }\end{array}$}} \\
\hline $\begin{array}{cc}\text { Sand } & \text { Si } \\
73 & 8\end{array}$ & $\begin{array}{c}\text { Clay } \\
19\end{array}$ & $\begin{array}{l}\text { Soil } \\
1.26\end{array}$ & & $\begin{array}{l}\text { icles } \\
65\end{array}$ & \multicolumn{2}{|c|}{$\begin{array}{l}\text { Micro } \\
26.98\end{array}$} & & & \multicolumn{2}{|c|}{$\begin{array}{l}\text { Total } \\
52.45\end{array}$} & & & \\
\hline \multirow{3}{*}{ Exchangeable } & $\mathrm{pH}$ & O.M & $S$ & P & K & $\mathrm{Ca}$ & $\mathrm{Mg}$ & $\mathrm{Al}$ & $\mathrm{H}+\mathrm{Al}$ & SB & CTC & V & $\mathrm{m}$ \\
\hline & $\left(\mathrm{CaCl}_{2}\right)$ & $\mathrm{g} \mathrm{dm}^{-3}$ & \multicolumn{2}{|c|}{$\mathrm{mg} \mathrm{dm}^{-3}$} & \multicolumn{7}{|c|}{----------------------'mmolc dm³-'----------------- } & \multicolumn{2}{|c|}{-----\%-------- } \\
\hline & 4.8 & 9.0 & 5 & 3 & 0.4 & 11 & 7 & 1 & 16 & 18.4 & 34.4 & 53 & 5 \\
\hline \multirow[t]{2}{*}{ Soluble } & $\begin{array}{c}\mathrm{pH} \\
\text { (paste) }\end{array}$ & $\begin{array}{c}\text { EC } \\
\mathrm{dS} \mathrm{m}^{-1}\end{array}$ & \multicolumn{2}{|c|}{$\mathrm{NO}_{3}^{-}$} & \multicolumn{2}{|c|}{$\mathrm{K}^{+}$} & & & \multicolumn{2}{|c|}{$\mathrm{Mg}^{2+}$} & \multicolumn{2}{|c|}{$\mathrm{SO}_{4}^{2-}$} & $\mathrm{Na}^{+}$ \\
\hline & 5.87 & 0.34 & \multicolumn{2}{|c|}{1.48} & \multicolumn{2}{|c|}{0.13} & 0. & & \multicolumn{2}{|c|}{0.48} & \multicolumn{2}{|c|}{0.41} & 0.66 \\
\hline
\end{tabular}

A complete randomized block design was used, arranged in a factorial scheme of 15 $x 3+1$ ), with four repetitions, totaling 64 plots. Each experimental unit was represented by one flowerbed. Plants were spaced $0.10 \mathrm{~m}$ and $1.0 \mathrm{~m}$ between rows, using the central meter of the plot as useful area and the other plants of the plot were considered as border.

Treatments were formed by the combination of five initial levels of soil salinity: 1.2; $2.3 ; 3.3,4.3$ and $5.5 \mathrm{dS} \mathrm{m}^{-1}$, which were maintained constant throughout the rose cycle; three nitrogen: potassium ( $\mathrm{N}$ : $\mathrm{K}$ ) ratios corresponding to $2: 1 ; 1: 2$ and 1:3; and a control (1: 1). In the $2: 1$ ratio, $66.6 \%$ of the amount of fertilizer to be applied from $\mathrm{N}$ and $33.4 \%$ from $\mathrm{K}$ were used. In the ratio $1: 2,33.4 \%$ came from $\mathrm{N}$ and $66.6 \%$ from $\mathrm{K}$; and for the ratio 1: 3, 25\% was from $\mathrm{N}$ and $75 \%$ from K. In the control (1:1) $50 \% \mathrm{~N}$ and $50 \% \mathrm{~K}$ were used.

The five levels of soil salinity were applied before transplanting to simulate saline soils at five different levels caused by excess of fertilizer salts in protected environment. The initial salinization of soil was performed through application of saline solution from the mixture of fertilizing salts (Eloi et al., 2007) which are presented in Table 2.

Table 2. Solubility and salinity index of fertilizers used as source of macronutrients for the preparation of salinizing solution.

\begin{tabular}{cccc}
\hline \multirow{2}{*}{ Fertilizers } & Solubility & \multicolumn{2}{c}{ Index } \\
\cline { 3 - 4 } & $\left(\mathrm{g} . \mathrm{L}\right.$ a $\left.20^{\circ} \mathrm{C}\right)$ & Global $^{*}$ & Partial $^{*}$ \\
\hline Calcium nitrate & 1200 & 52.5 & 4.41 \\
Potassium nitrate & 310 & 73.6 & 11.58 \\
Ammonium nitrate & 1900 & 69.0 & 3.25 \\
Phosphate monopotassium & 2300 & 34.3 & 0.64 \\
Magnesium sulphate & 500 & 46.1 & 0.85 \\
\hline
\end{tabular}

* Relative value obtained when compared to sodium nitrate $\left(\mathrm{NaNO}_{3}\right)$. Global when compared independent of its composition and partial when compared by units of nutrients. 
Relative value obtained when compared to sodium nitrate $\left(\mathrm{NaNO}_{3}\right)$. Global when compared independent of its composition and partial when compared by units of nutrients.

The concentration of fertilizer solution to maintain the five initial levels of electrical conductivity increased and was proportional to the initially proposed N: K ratios, and the levels of initial electrical conductivity of soil were estimated by Richards equation and calibrated to the specific situation.

Samourai ${ }^{\circledR}$ Meikatana roses were used. Seedlings were obtained from piles of commercial production area matrices with two complete leaves pairs, transplanted in single row, spaced $1.0 \mathrm{~m}$ between rows and $0.1 \mathrm{~m}$ between plants. Weekly pruning was performed (buds removal) aiming at the formation and growth of as many branches and leaves as possible, allowing the accumulation of carbohydrates in the stems which were later used in the formation of the basal branches. At 110 days after transplanting (DAT), the basal branch was pruned at a height of $0.60 \mathrm{~m}$, so the rose started to produce commercial stems.

Drip irrigation system was adopted, using self-compensating emitters, with a nominal flow rate of $4 \mathrm{~L} \mathrm{~h}^{-1}$, which were previously evaluated under normal operating conditions, presenting distribution uniformity coefficient of $97.3 \%$. The drippers were coupled to the irrigation rows (polyethylene tubes), and solenoid valves were installed in all plots (automation of the irrigation system), so it was possible to apply different volume of water for each treatment. Irrigation management was performed using soil moisture data obtained by TDR probe, with rods installed at 0.20 and $0.40 \mathrm{~m}$ depth, and the humidity was also monitored by tensiometers.

After pruning, in the vegetative phase, nutrient amounts were applied according to the recommendation of Feigin et al. (1986) (Table 3).

Table 3. Nutrients recommendation for the production phase of rose crops

\begin{tabular}{|c|c|c|c|c|c|c|c|c|c|c|c|}
\hline Nutrients & $\mathrm{N}$ & $\mathrm{P}$ & $\left(\mathrm{K}_{2} \mathrm{O}\right)$ & $\mathrm{Ca}$ & $\mathrm{Mg}$ & $S$ & $\mathrm{Zn}$ & $\mathrm{Cu}$ & $\mathrm{Fe}$ & $\mathrm{Mn}$ & $\mathrm{B}$ \\
\hline (g plant ${ }^{-1}$ year-1) & $20 *$ & 5.50 & $20^{*}$ & 5.40 & 1.71 & 1.30 & 0.05 & 0.013 & 0.20 & 0.06 & 0.04 \\
\hline
\end{tabular}

Nitrogen fertigation was applied in the nutrient solution with $25 \% \mathrm{NH}_{4}+$ and $75 \% \mathrm{NO}_{3}$.

Up to 110 days after transplanting (DAT), the same recommendation applied in the control treatment was used for all treatments. However, after this, the treatments were differentiated according to soil salinity levels and nitrogen: potassium ratios. Thus, fertigation was only performed when the soil electrical conductivity was around $10 \%$ below the initial levels of salinity pre-established for each treatment.

The amount of fertilizers applied and their ratio were calculated so that the soil solution could recover the initial EC level $(1.2,2.3,3.3,4.3$ and $5.5 \mathrm{dS} \mathrm{m}^{-1}$ ), being performed from a curve that related electrical conductivity $\left(\mathrm{dS} \mathrm{m}^{-1}\right)$ with solution concentration $\left(\mathrm{Mg} \mathrm{L}^{-1}\right)$, presented in equation 1.

$$
\mathrm{CEA}=\frac{\mathrm{CEF} \cdot \mathrm{VV} \cdot \theta \mathrm{CC}-\mathrm{CEE} \cdot \mathrm{VV} \cdot \theta \mathrm{A}}{\mathrm{VCC}}
$$

In which: ECA - electrical conductivity of the fertigation solution to be applied, dS $\mathrm{m}^{-1}$; FEC - final electrical conductivity of fertilizer salts solutions in the field capacity, dS $\mathrm{m}^{-1}$; VT - Volume of soil contained in the trench, L; eCC - volumetric moisture content in the field capacity, $\mathrm{L}^{-1}$; ECE - electrical conductivity of soil solution measured by TDR probe and porous capsule extractors, $d S \mathrm{~m}^{-1} ; \quad \theta A$ - volumetric moisture (immediately prior to fertigation), $\mathrm{L} \mathrm{L}^{-1}$; VCC volume of solution required for the soil to reach the field capacity, L.

During the phase of rose production, soil solution monitoring was carried out with the aid of TDR probe, and the electrical conductivity (EC), nitrate $\left(\mathrm{NO}_{3}{ }^{-}\right)$and potassium $\left(\mathrm{K}^{+}\right)$concentrations were measured following the parameterization of Rhoads et al. (1976) (equation 2):

$$
\mathrm{CE}=(\mathrm{CEaCEs}) /\left(\mathrm{a} \theta^{2}+b \theta\right)
$$


In which EC - electrical conductivity in soil solution (dS $\mathrm{m}^{-1}$ ); $\mathrm{ECa}$ - apparent electrical conductivity of soil determined by TDR (dS $\mathrm{m}^{-1}$ ); ECS - electrical conductivity of the solid fraction of the soil, directly associated with ion exchange at the soil solid-liquid interface and it is normally considered a constant value for each soil ( $d S$ $\left.\mathrm{m}^{-1}\right) ; \theta$ - volumetric moisture $\left(\mathrm{m}^{3} \mathrm{~m}^{-3}\right)$; " $a$ " and "b" - leveling parameters (dimensionless).

Laboratory analyses were performed to obtain the electrical conductivity of the saturation extract, providing a calibration through the correlation of data collected with the TDR and data obtained in the laboratory. Electrical conductivity (EC) was analyzed by a conductivimeter with automatic temperature compensation; Nitrate $\left(\mathrm{NO}_{3}^{-}\right)$was measured using an electrochemical sensor and potassium $(K+)$ concentrations were determined by flame emission photometry, expressed in $\mathrm{mg} \cdot \mathrm{L}^{-1}$.

After harvest, which was performed at 245 DAT, plant material was collected and submitted to oven drying. After weighing the

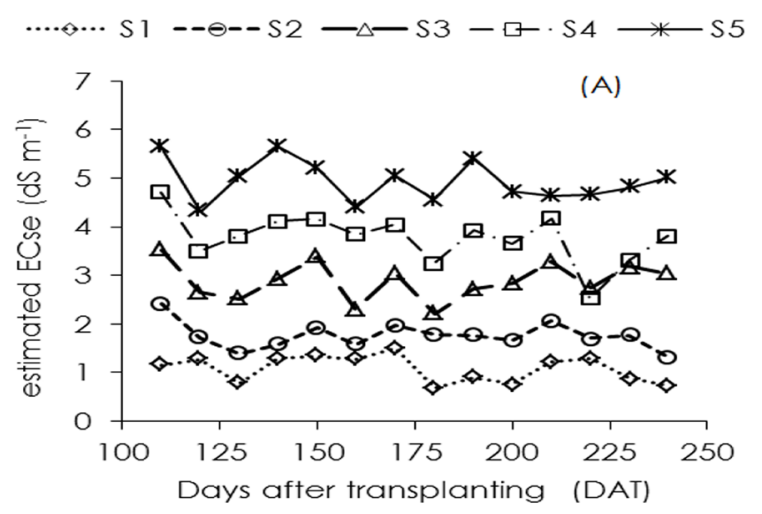
dry mass of leaves, stems and flower buds, the

samples were ground and sent to the Laboratory of Plants Mineral Nutrition of ESALQ / USP to determine macronutrient content (N, K, P, Ca, Mg and S), according to the modified methodology of Malavolta et al. (1997).

Variables were analyzed statistically by $F$ test, and the analyses were deployed whenever the interaction was significant. The quantitative factors related to electrical conductivity levels of the soil solution were analyzed statistically through polynomial regression (linear and quadratic), while the qualitative parameters were analyzed through Tukey's test at $5 \%$ probability.

\section{Results and Discussion}

Soil salinity monitoring

The values of electrical conductivity of soil saturation extract (ECs) estimated with TDR are presented in Figure 1, and Figures A, B and $C$ represent the behaviors of $N: K$ ratios $(2: 1,1$ : 2 and 1: 3), respectively. For all N: K ratios, the curves suffered a marked variation along the crop cycle. The maintenance of initial salinity levels by monitoring the estimated soil electrical conductivity by TDR allowed the initial levels to be maintained throughout the crop cycle.
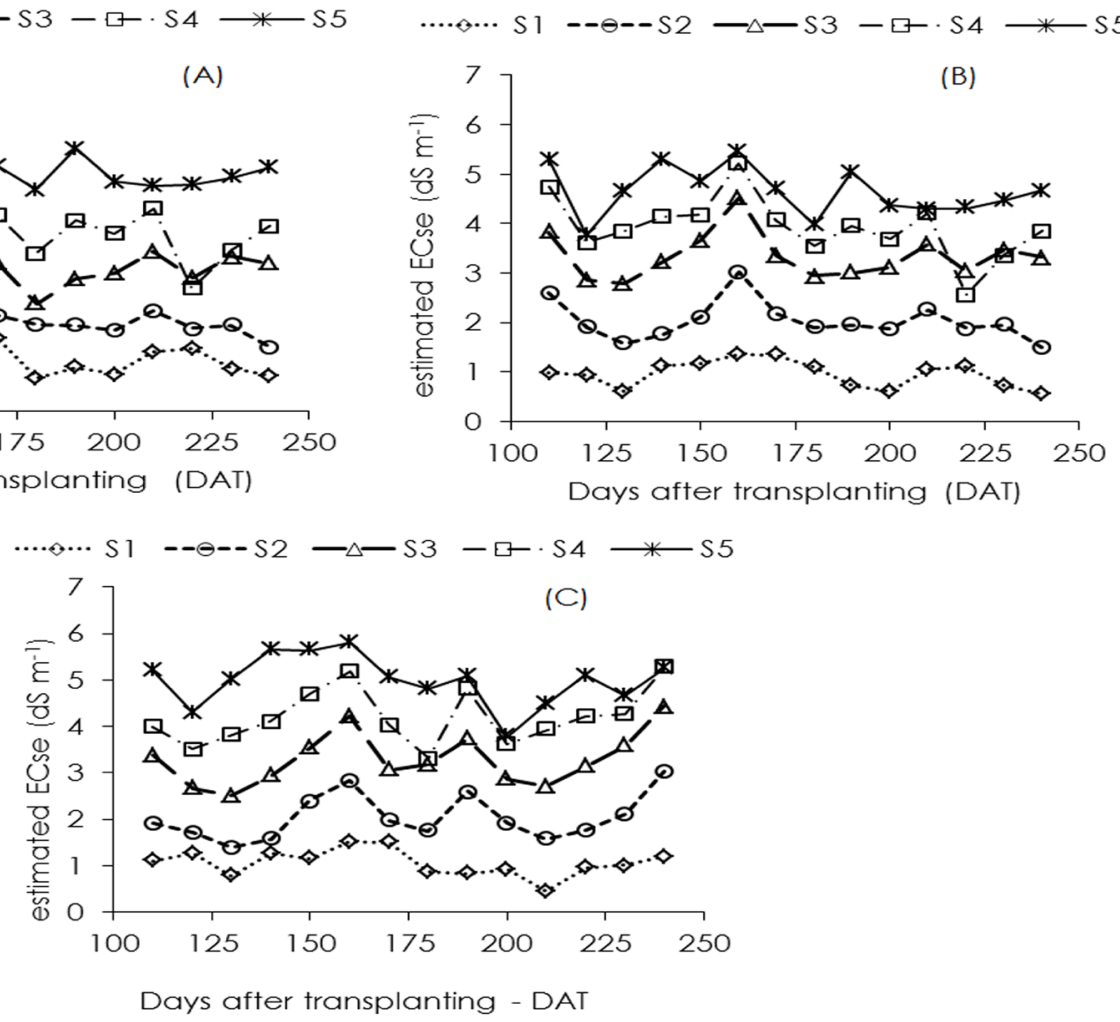

Figure 1. Electric conductivity values of soil saturation extract $(E C S)$ obtained by TDR during rose $c y c l e(S 1=1.2 ; S 1=2.3 ; S 1=3.3 ; S 1=4.3$ e $\mathrm{S} 1=5.5 \mathrm{dS}^{-1}$ ), for $\mathrm{N}: \mathrm{K}$ ratios $2: 1(\mathrm{~A}) ; 1: 2$ (B) and $1: 3(\mathrm{C})$ respectively. 
Analyzing the relationship between EC (TDR) and EC determined in laboratory (Figure $2 \mathrm{~A}$ ), a correlation of $92.72 \%$ was verified, with a coefficient of determination of $86.04 \%$. Thus, the measured electrical conductivity and $\mathrm{NO}_{3}$ and $\mathrm{K}+$ concentrations determined in laboratory were correlated, obtaining the equation (3) for potassium and equation (4) for nitrate.

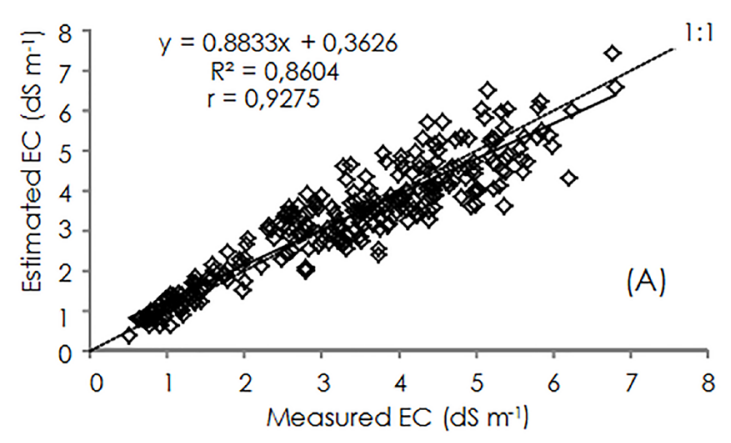

Measured $\mathrm{EC}=0.0149\left(\mathrm{~K}^{+}\right)-0.1261$

(3)

Measured $\mathrm{EC}=0.0008 \times\left(\mathrm{NO}_{3}^{-}\right)-1.5785$

Potassium concentration (Figure $2 \mathrm{~B}$ ) in soil solution was estimated through the replacement of equation 3 in equation 2, by TDR technique. For the adjustment of potassium regression equation, there was a correlation of $84.62 \%$ between the estimated and observed data with determination coefficient of $71.61 \%$.

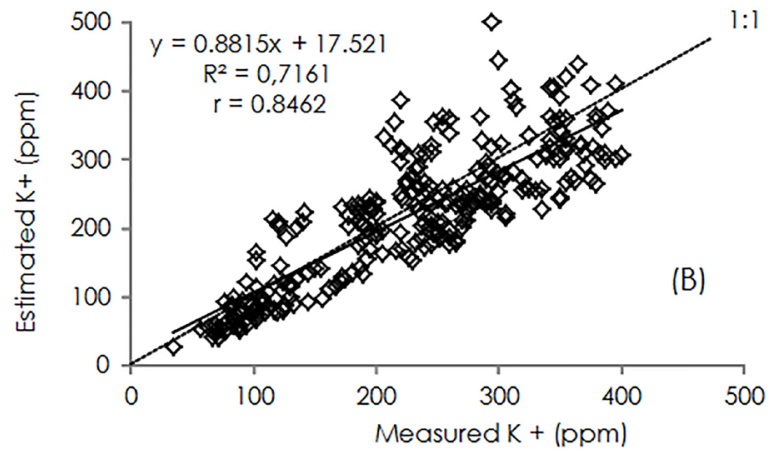

Figure 2. Electrical conductivity estimated by TDR and measured in laboratory (A) and $K+$ estimated by TDR and measured in laboratory (B)

Nitrate concentration in soil solution was estimated by TDR (Figure 3), by replacing equation 4 in equation 2. For the adjustment of nitrate values with the values estimated by TDR, a correlation of $81.49 \%$ between the estimated and observed data was observed, and a determination coefficient of $66.41 \%$, which was lower than the one obtained by Santos et al. (2009) who found 0.98 when estimating nitrate in soil solution in laboratory by TDR.

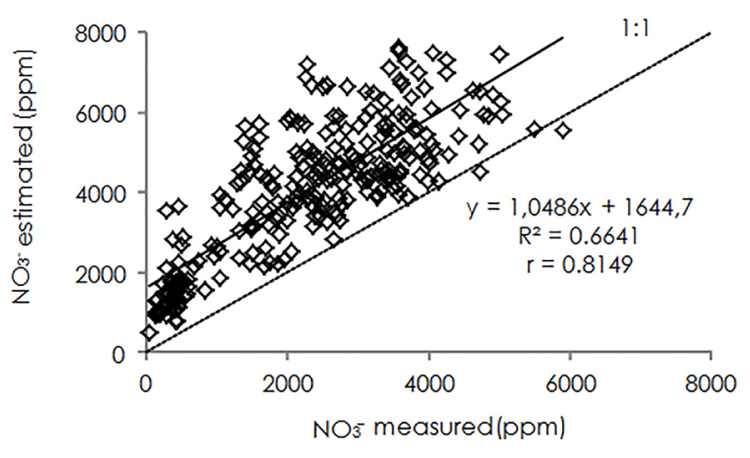

Figure 3. $\mathrm{NO}_{3}$ - estimated by TDR and measured in laboratory.

Lopes et al. (2010), studying a Quartzarenic Neosol, obtained satisfactory results of EC determination soil solution by TDR, demonstrating a linear association between soil solution extractor techniques and TDR.

According to Souza et al. (2007), there is a tendency to increase the use of TDR technique for precise measurements of soil moisture and electric conductivity. They also recommend a calibration curve for each type of soil and this inconvenience is usually acceptable when compared to the advantages that this technique presents in relation to soil solution extractors.

Nitrogen e potassium

There was a significant linear effect ( $\mathrm{p}$ $<0.01$ ) for soil salinity levels and N: K ratios in all 
variables and no significant effect was observed for the interaction among the factors (Table 4).

In the comparison between control and other treatments, there was a significant difference $(p<0.01)$ for $N S, N B$ and NL. For

potassium, a significant difference $(p<0.05)$ was observed only for KL.

At 245 DAT, nitrogen content in the leaves $(\mathrm{NL})$ was higher than in flower buds (NB), which was superior to nitrogen in the stems (NS) (Figure

Table 4. Summary of variance analysis of nitrogen content in the stem (NS), nitrogen in the floral bud (NB) nitrogen in the leaf (NL), potassium in the stem (KS), potassium in the floral bud (KB) and potassium in the leaf (KL). PiracicabaSP, 2012.

\begin{tabular}{|c|c|c|c|c|c|c|c|}
\hline \multirow{2}{*}{ Source of variation } & \multirow{2}{*}{ DF } & \multicolumn{6}{|c|}{ F Test } \\
\hline & & NS & NB & $\mathrm{NL}$ & KS & $\mathrm{KB}$ & $\mathrm{KL}$ \\
\hline Salinity (S) & 4 & $190.16^{* *}$ & $40.32 * *$ & $97.04^{* *}$ & $166.28^{* *}$ & $78.81^{* *}$ & $39.10^{* *}$ \\
\hline Linear & - & $759.38^{* *}$ & $153.40^{* *}$ & $383.43^{* *}$ & $647.66^{* *}$ & $305.53^{* *}$ & $152.41^{* *}$ \\
\hline Quadatic & - & $0.93^{\text {ns }}$ & $4.50 *$ & $0.37^{\text {ns }}$ & $2.23^{\text {ns }}$ & $8.56^{* *}$ & $2.64^{\mathrm{ns}}$ \\
\hline $\mathrm{N}: \mathrm{K}$ ratio $(\mathrm{R})$ & 2 & $22.96^{* *}$ & $3.66^{* *}$ & $8.93^{* *}$ & $36.68^{* *}$ & $19.10^{* *}$ & $8.49^{* *}$ \\
\hline SXR & 8 & $1.44^{\mathrm{ns}}$ & $0.60^{\text {ns }}$ & $0.61^{\mathrm{ns}}$ & $1.26^{\mathrm{ns}}$ & $2.98^{n s}$ & $1.98^{\mathrm{ns}}$ \\
\hline Factorial x Control & 1 & $50.57^{* *}$ & $13.02^{* *}$ & $164.57^{* *}$ & $0.13^{\text {ns }}$ & $1.52^{\text {ns }}$ & $3.28^{*}$ \\
\hline Treatment & 15 & $57.91^{* *}$ & $12.43^{* *}$ & $38.36^{* *}$ & $50.98^{* *}$ & $24.99^{* *}$ & $12.83^{* *}$ \\
\hline $\mathrm{CV}(\%)$ & - & 3.74 & 4.37 & 4.28 & 3.62 & 4.68 & 6.07 \\
\hline Overall mean $\left(\mathrm{g} \mathrm{Kg}^{-1}\right)$ & - & 12.43 & 15.05 & 19.61 & 10.44 & 11.94 & 15.67 \\
\hline
\end{tabular}

4A). It was observed that all presented a linear behavior in response to the increase of salinity levels, with the higher contents obtained in the higher salinities; for NL, maximum values of 20.40 $\mathrm{g} \mathrm{kg}^{-1}$ were obtained with percentage increases between the lowest and highest soil salinity of $27.26 \%$. For the variable NB, the maximum values were $16.79 \mathrm{~g} \mathrm{~kg}^{-1}$ with an increase of $23.46 \%$; for NS, the maximum value was $15.00 \mathrm{~g} \mathrm{~kg}^{-1}$, but with the greatest percentage difference (49.55\%) between the extreme levels of salinity.

For potassium (Figure 4B), the behavior was very similar to nitrogen, being higher in the leaves (KF), then in floral buds (KB) and

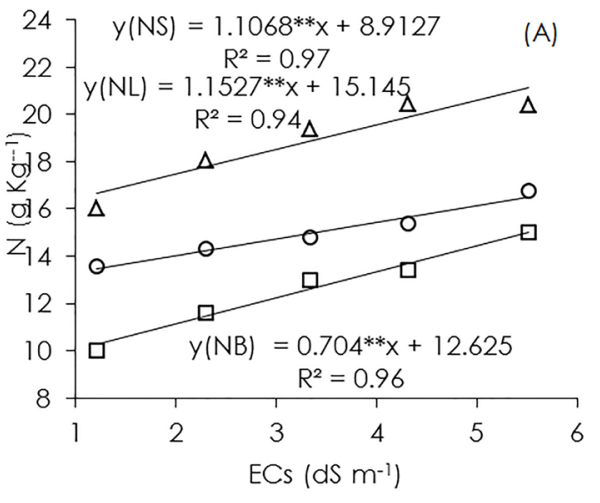

$\square \mathrm{NH}$

ONB

$\Delta \mathrm{NF}$

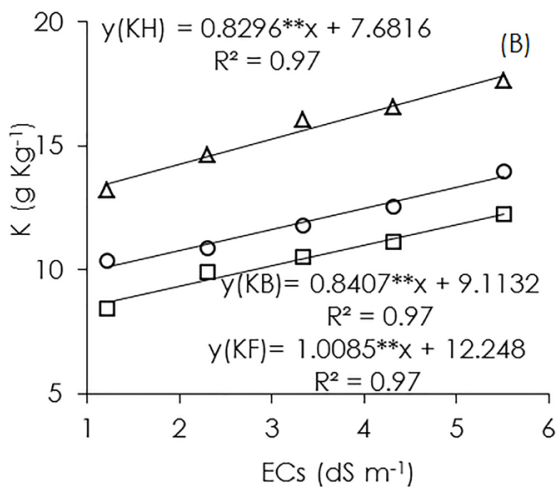

$\square \mathrm{KH} \quad \mathrm{KB} \quad \Delta \mathrm{KF}$

Figure 4. Content in $\mathrm{g} \mathrm{kg}^{-1}$ of nitrogen in the stem (NS), nitrogen in the floral bud (NB) Nitrogen in the leaf (NL) (A) and potassium in the stem (KS), potassium in floral bud (KB) and potassium in the leaf (KL), (B) at 245 DAT, for rose crops, as a function of salinity levels and nitrogen: potassium ratios.

lower in the stems $(\mathrm{KH})$. With maximum levels of 17.79; 13.74 and $12.24 \mathrm{~g} \mathrm{~kg}^{-1}$ for $\mathrm{KL}, \mathrm{KB}$ and $\mathrm{KS}$, respectively, in proportional terms of increases between the lowest and the highest salinity level, the increase was the opposite of the contents, with $44.70 ; 34.77$ and $33.30 \%$ increase for $\mathrm{KS}, \mathrm{KB}$ and $\mathrm{KL}$ respectively.

For nitrogen in the leaves (NL), the variation between the lowest and the highest salinity level was 1.6 to $2.0 \%$. According to Cadahía et al. (1998) who studied nutrient uptake in hydroponic roses, observed average values of $\mathrm{N}$ and $\mathrm{K}$ in the leaves of 2.84 and $2.50 \%$, respectively. Therefore, these results are superior to the nitrogen content of the present research. For the same author, the absorption of potassium in the plant tissues of rose increases due to the greater absorption of nitrate than ammonium, 
providing a greater demand for $\mathrm{K}$.

The results of $K$ levels observed in the leaves varied from 1.3 to $1.7 \%$, and the highest content was in the most saline treatment, which corroborates with other authors that found values of $K$ varying from 1.8 to $2.7 \%$ (Vetanovetz, 1996; Mills \& Jones, 1996), which are lower than the values observed by Casarini (2004), with values higher than $2.54 \%$.

Probably, the increase of these levels as the salinity levels increased, is due to the fact that the highest level of salinity conditioned a greater availability of $K$ for the plants through the direct addition of the element in the soil, promoting a greater accumulation in plant tissues.

Comparing the average levels of $\mathrm{N}$ and
$\mathrm{K}$ in the leaves between the lowest and highest salinity levels, a N: K ratio of 1.18 was observed, a result similar to that observed by Casarini (2004), with the same relation $\mathrm{N}: \mathrm{K}$ of 1.17 . These values are higher than those found by Burt et al. (1998) which recommended a ratio of 1 in fertilization programs.

In relation to nitrogen, the control treatment presented superior results to other factorial treatments for all harvests. For potassium it was only observed in the last harvest at 245 DAT. The other interactions were statistically the same at 0.05 probability by Tukey's test (Table 5). Phosphorus and calcium

According to the analysis of variance for phosphorus content in the stem (PS), floral bud

Table 5. Mean values in ( $\mathrm{g} \mathrm{kg}^{-1}$ ) of nitrogen contents in stem (NS), nitrogen in floral bud (NB), nitrogen in the leaf $(\mathrm{NL})$, potassium in the stem (KS), potassium in floral bud (KB) and potassium in the leaf(KF). Piracicaba- SP, Brazil 2012.

\begin{tabular}{|c|c|c|c|c|c|c|}
\hline Ratios & NS & NB & $\mathrm{NL}$ & KS & $K B$ & $\mathrm{KL}$ \\
\hline $2: 1$ & $11.83 C$ & $14.71 \mathrm{~B}$ & $18.69 \mathrm{~B}$ & $9.95 \mathrm{C}$ & $11.41 \mathrm{C}$ & $14.94 \mathrm{~B}$ \\
\hline $1: 2$ & $12.31 \mathrm{~B}$ & $14.94 \mathrm{AB}$ & 19.27AB & $10.42 B$ & $11.91 \mathrm{~B}$ & $15.75 \mathrm{~A}$ \\
\hline $1: 3$ & $12.82 \mathrm{~A}$ & $15.27 \mathrm{~A}$ & $19.82 \mathrm{~A}$ & $10.98 \mathrm{~A}$ & $12.44 \mathrm{~A}$ & $16.15 \mathrm{~A}$ \\
\hline \multicolumn{7}{|c|}{ Factorial x Control } \\
\hline Factorial Mean & $12.32 b$ & $14.97 \mathrm{~b}$ & $19.26 b$ & $10.45 a$ & $11.92 \mathrm{a}$ & $15.61 \mathrm{~b}$ \\
\hline Control Mean & $14.03 a$ & $16.20 \mathrm{~A}$ & $24.82 a$ & $10.38 a$ & $12.28 a$ & $16.50 a$ \\
\hline DMS & 0.36 & 0.50 & 0.64 & 0.29 & 0.43 & 0.73 \\
\hline
\end{tabular}

$(\mathrm{PB})$, and leaf $(\mathrm{PL})$, calcium in the stem (CaS), floral bud (CaB) and leaf (CaL) at 245 DAT (Table 6), there was a significant linear effect ( $p<0.01$ ) for soil salinity levels for all variables.

For $\mathrm{N}$ : K ratios, a significant difference ( $\mathrm{p}<0.01$ ) was observed only for $\mathrm{CaL}$, and also between the control and the other treatments, for the same variable.

Phosphorus content in the stems (PS) and buds (PB) (Figure 5A) increased significantly and linearly in response to the increase of salinity levels. The highest levels were obtained in the highest doses of fertilizers, and the maximum values for PS and PB were $2.38 \mathrm{~g} \mathrm{~kg}^{-1}$, with percentage increases between the lowest and the highest salinity level of $27.9 \%$ and $32.9 \%$ for stems and buds, respectively. In the leaves the behavior was quite similar. However, with lower

Table 6. Summary of analysis of variance of phosphorus content in stem (PS), floral bud (PB), leaf (PL), calcium in the stem (CaS), floral bud (CaB), and leaf (CaL). Piracicaba- SP, 2012.

\begin{tabular}{|c|c|c|c|c|c|c|c|}
\hline \multirow{2}{*}{ Source of Variation } & \multirow{2}{*}{ DF } & \multicolumn{6}{|c|}{ F Test } \\
\hline & & PS & PB & $\mathrm{PL}$ & Cas & $\mathrm{CaB}$ & $\mathrm{CaL}$ \\
\hline Salinity (S) & 4 & $4.54^{* *}$ & $3.94^{* *}$ & $3.24^{* *}$ & $15.27^{* *}$ & $15.27^{* *}$ & $152.1^{* *}$ \\
\hline Linear & - & $15.16^{* *}$ & $14.78^{* *}$ & $11.90^{* *}$ & $57.57^{* *}$ & $57.57^{* *}$ & $586.91^{* *}$ \\
\hline Quadratic & - & $1.35^{\mathrm{ns}}$ & $0.009^{n s}$ & $0.80^{\text {ns }}$ & $0.30^{\text {ns }}$ & $0.30^{\text {ns }}$ & $19.31^{* *}$ \\
\hline Ratio N:K (R) & 2 & $0.76^{\mathrm{ns}}$ & $2.15^{\text {ns }}$ & $1.63^{\text {ns }}$ & $2.60^{\text {ns }}$ & $2.60^{\mathrm{ns}}$ & $12.27^{* *}$ \\
\hline SXR & 8 & $1.44^{\mathrm{ns}}$ & $0.66^{\mathrm{ns}}$ & $2.28^{\text {ns }}$ & $0.38^{\text {ns }}$ & $0.38^{\text {ns }}$ & $1.44^{\mathrm{ns}}$ \\
\hline Factorial x Control & 1 & $0.19^{\text {ns }}$ & $0.003^{\text {ns }}$ & $0.33^{\text {ns }}$ & $2.41^{\mathrm{ns}}$ & $2.41^{\mathrm{ns}}$ & $12.42^{* *}$ \\
\hline Treatment & 15 & $2.09 *$ & $1.69^{\text {ns }}$ & $2.32 *$ & $4.78^{* *}$ & $4.78^{* *}$ & $43.79 * *$ \\
\hline CV $(\%)$ & - & 19.23 & 18.19 & 24.15 & 15.08 & 15.08 & 5.88 \\
\hline Overall mean $\left(\mathrm{g} \mathrm{Kg}^{-1}\right)$ & - & 2.06 & 2.07 & 1.69 & 2.99 & 2.99 & 9.35 \\
\hline
\end{tabular}


contents and with a maximum PL of $1.99 \mathrm{~g} \mathrm{Kg}$ ', and a percentage increase of $33.55 \%$ between extreme levels.

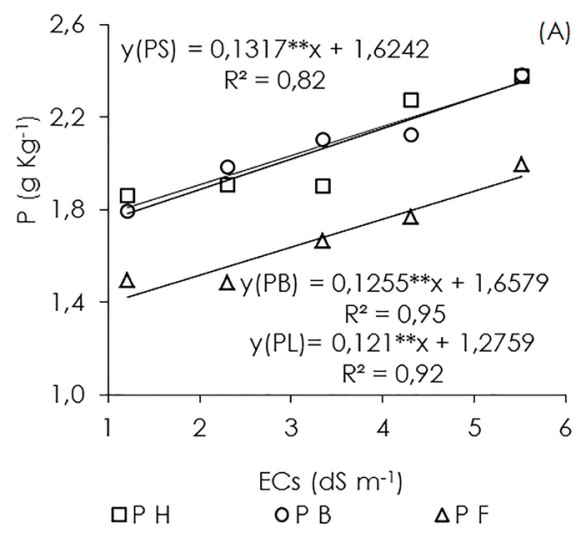

Figure $5 \mathrm{~B}$ shows that calcium content in the leaves (CaL) increased significantly and linearly in response to increased soil salinity levels,

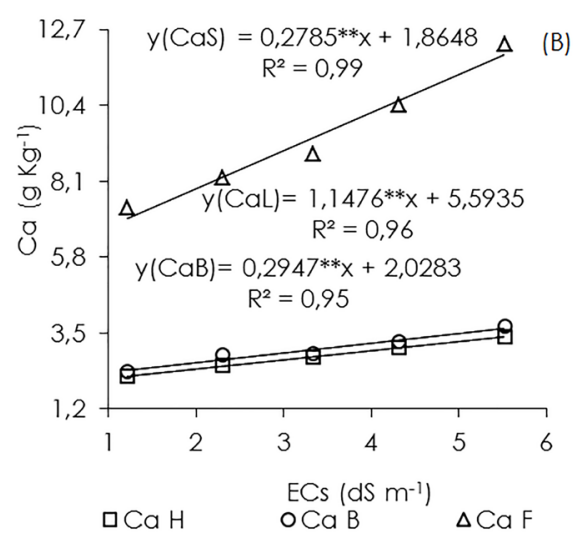

Figure 5. Contents in $\mathrm{g} \mathrm{Kg}^{-1}$ of phosphorus in the stem (PS), phosphorus in the floral buds (PB), phosphorus in the leaf $(\mathrm{PL}),(\mathrm{A})$ and calcium in the stem (CaS), calcium in the floral bud (CaB) and calcium in leaf (CaL) (B) at 245 DAT, for rose crops, as a function of salinity levels and nitrogen: potassium ratios.

obtaining maximum values at the highest salinity level of $12.26 \mathrm{~g} \mathrm{Kg}^{-1}, 68.17 \%$ higher than the lowest level. Therefore, the opposite of that observed for phosphorus, in which the highest levels were found in the stems and floral buds, with values of 3.39 and $3.72 \mathrm{~g} \mathrm{Kg}^{-1}$, with increases of 55.5 and $58.2 \%$ relative to the lowest and highest salinity levels, respectively.

Calcium variation in the leaves between the lowest and the highest level of soil salinity was 0.7 to $1.2 \%$, respectively. Mills \& Jones (1996), studying hybrids of roses, observed mean values of calcium in the leaves of up to $2.33 \%$ and minimum values of $1.0 \%$, which is very close to the ones found in this study.

Calcium contents in the leaves increased as levels of soil salinity increased too. These results do not corroborate with those obtained by Casarini (2004), who obtained a drop of $11.4 \%$ in Ca content in rose leaves, increasing $\mathrm{K}$ doses varying from 10 to $40 \mathrm{~g}_{\text {plant year }}{ }^{-1}$. This drop is influenced by many factors such as characteristics of the cultivar, root system, form and frequency of fertilizer application, volatilization, soil physical and chemical properties.

In Table 7, it is observed that the control treatment was inferior to the other factorial treatments at 245 DAT for calcium in the leaf $(\mathrm{CL})$. The other interactions were statistically the same at 0.05 probability by Tukey test.

Dutra (2009) evaluating the nutrition of two cultivars of roses (Vegas and Tineke) under nutrients omission, verified P leaf content of $2.52 \mathrm{~g}$ Table 7. Mean values in $\left(\mathrm{g} \mathrm{kg}^{-1}\right)$ for phosphorus content in the stem (PS); floral bud (PB), leaf (PL), calcium in the stem (CaS), floral bud (CaB), leaf (CaL). Piracicaba - SP, 2012.

\begin{tabular}{ccccccc}
\hline Ratios & P S & P B & P L & Ca S & Ca B & Ca L \\
\hline $2: 1$ & $2.12 \mathrm{~A}$ & $1.98 \mathrm{~A}$ & $1.55 \mathrm{~A}$ & $2.84 \mathrm{~A}$ & $2.84 \mathrm{~A}$ & $8.98 \mathrm{~B}$ \\
$1: 2$ & $1.98 \mathrm{~A}$ & $2.03 \mathrm{~A}$ & $1.78 \mathrm{~A}$ & $3.02 \mathrm{~A}$ & $3.02 \mathrm{~A}$ & $9.46 \mathrm{~A}$ \\
$1: 3$ & $2.09 \mathrm{~A}$ & $2.22 \mathrm{~A}$ & $1.70 \mathrm{~A}$ & $3.17 \mathrm{~A}$ & $3.17 \mathrm{~A}$ & $9.84 \mathrm{~A}$ \\
\hline Factorial x Control & & & & & & \\
\hline Factorial Mean & $2.06 \mathrm{a}$ & $2.08 \mathrm{a}$ & $1.68 \mathrm{a}$ & $3.01 \mathrm{a}$ & $3.01 \mathrm{a}$ & $9.43 \mathrm{a}$ \\
Control Mean & $1.98 \mathrm{a}$ & $2.07 \mathrm{a}$ & $1.80 \mathrm{a}$ & $2.89 \mathrm{a}$ & $2.69 \mathrm{a}$ & $8.42 \mathrm{~b}$ \\
\hline DMS & 0.30 & 0.29 & 0.31 & 0.34 & 0.34 & 0.42
\end{tabular}

Means followed by the same uppercase letter in the rows, and lower case in the columns do not differ according to Tukey's test at 0.05 of probability.

$\mathrm{kg}^{-1}$ in the plants submitted to complete nutritional solution, which is higher than in the present study. According to Vetanovetz (1996), the appropriate range of $P$ in the leaf of rose is 1.5 to $3.0 \mathrm{~g} \mathrm{~kg}^{-1}$. Thus, the plants of this study presented levels of $\mathrm{P}$ very close to the recommendation.

Magnesium and sulfur

There was a significant linear effect $(p$ $<0.01$ ) for the values of magnesium and sulfur 
in the stems, floral buds and leaves at 245 DAT (Table 8). For soil salinity levels, there was a significant effect only for magnesium. In N: K ratios and in their interaction with soil salinity levels, no significance was observed for both elements.

In the comparison between the control and the other treatments, there was a significant

Table 8. Summary of the variance analysis for magnesium content in the stem (MgS), in the floral bud (MgB), in the leaf (MgL), sulfur in the stem (SS), in the flower bud (SB), in the leaf (SL). Piracicaba - SP, 2012

\begin{tabular}{lccccccc}
\hline \multirow{2}{*}{ Source of variation } & \multirow{2}{*}{ DF } & \multicolumn{7}{c}{ F Test } \\
\cline { 3 - 7 } & & $M g S$ & $M g B$ & $M g L$ & $S S$ & $S B$ & $S L$ \\
\hline Salinity (S) & 4 & $1.65^{*}$ & $1.66^{*}$ & $8.44^{* *}$ & $3.46^{\text {ns }}$ & $2.95^{\text {ns }}$ & $1.55^{\text {ns }}$ \\
$\quad$ Linear & - & $4.48^{*}$ & $4.73^{*}$ & $22.18^{* *}$ & $1.25^{\text {ns }}$ & $5.13^{\text {ns }}$ & $3.51^{\text {ns }}$ \\
$\quad$ Quadratic & - & $0.18^{\text {ns }}$ & $0.17^{\text {ns }}$ & $5.25^{*}$ & $0.06^{\text {ns }}$ & $5.34^{\text {ns }}$ & $1.04^{\text {ns }}$ \\
N:K Ratio (R) & 2 & $2.79^{\text {ns }}$ & $2.79^{\text {ns }}$ & $1.62^{\text {ns }}$ & $0.17^{\text {ns }}$ & $3.31^{\text {ns }}$ & $2.48^{\text {ns }}$ \\
SxR & 8 & $1.05^{\text {ns }}$ & $1.05^{\text {ns }}$ & $0.68^{\text {ns }}$ & $1.74^{\text {ns }}$ & $1.45^{\text {ns }}$ & $1.37^{\text {ns }}$ \\
Factorial x Control & 1 & $6.91^{*}$ & $6.91^{*}$ & $13.88^{* *}$ & $0.98^{\text {ns }}$ & $0.06^{\text {ns }}$ & $0.02^{\text {ns }}$ \\
Treatment & 15 & $1.83^{\text {ns }}$ & $1.83^{\text {ns }}$ & $3.77^{* *}$ & $1.94^{\text {ns }}$ & $2.00^{\text {ns }}$ & $1.47^{\text {ns }}$ \\
\hline CV (\%) & - & 29.76 & 29.76 & 15.53 & 44.68 & 42.15 & 31.78 \\
Overall Mean $\left(\mathrm{g} \mathrm{kg}^{-1}\right)$ & - & 1.17 & 1.17 & 2.43 & 0.68 & 0.83 & 1.20 \\
\hline
\end{tabular}

Means followed by the same uppercase letter in the rows, and lower case in the columns are not different according to Tukey's test at 0.05 of probability.

salinity levels increase, with maximum values of MgS and MgB values were 1.25 and $2.95 \mathrm{~g} \mathrm{~kg}^{-1}$ with percentage increases between the lowest and highest salinity levels of $35.8 \%$ and $33.5 \%$ for stems and buds, respectively. In the leaves the behavior was very similar, but with much higher contents, with a maximum MgL of $12.26 \mathrm{~g} . \mathrm{Kg}^{-1}$, and increase percentage of $68.17 \%$ between the lowest and highest salinity level. Similar results were obtained by Lima (2013), in which the increase in $\mathrm{N}$ doses caused an increase in $\mathrm{Mg}$ content in the leaves, stems and buds.

There was no significant effect among treatments on sulfur content (Figure 6B) in all evaluated parts. Mean values were $0.67 ; 1.20$ and $0.83 \mathrm{~g} \mathrm{~kg}^{-1}$, for SS, SL and SB, respectively.

$\mathrm{Mg}$ content in the leaves followed the

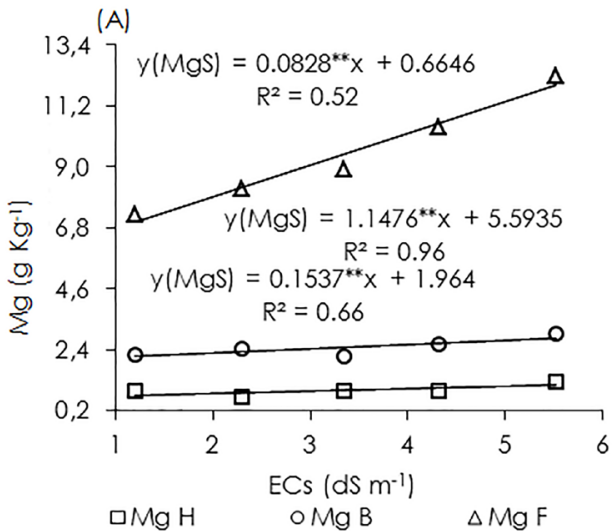

difference ( $\mathrm{p}<0.05$ ) for $\mathrm{MgS}$ and $\mathrm{MgB}$ and for $\mathrm{MgL}(\mathrm{p}<0.01)$. For sulfur, no significant difference was observed.

Magnesium content in the stems (MgS), buds (MgB) and leaves (MgL) (Figure 6A) increased significantly and linearly in response to same tendency of $\mathrm{Ca}$, increasing in relation to the increase of salinity levels. The mean values varied between 0.72 and $1.22 \%$ for treatments with the lowest and highest levels of soil salinity, respectively; These results were higher than those obtained by Casarini (2004), but with different behavior, since there was a reduction in the content of this element as potassium doses increased from 0.28 to $0.23 \%$.

For magnesium, it was verified that the control treatment was inferior to the other factorial treatments in all analyzed parts (stem, bud and leaf). The other interactions were statistically the same at 0.05 probability by Tukey test (Table 9).

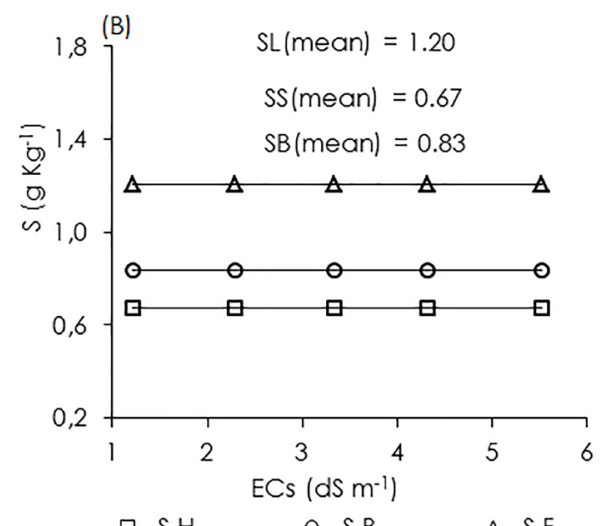

Figure 6. Content of magnesium ( $\mathrm{g} \mathrm{kg}^{-1}$ ) in the stem (MgS), in the floral bud (MgB), in the leaf (MgL) (A) and sulfur in the stem (SS), in flower bud (SB) and in the leaf (SL) (B) at 245 DAT for rose crops, as a function of salinity levels and nitrogen: potassium ratios 
Table 9. Mean values $\left(\mathrm{g} \mathrm{kg}^{-1}\right)$ of magnesium contents in the stem (MgS); in floral bud (MgB); in the leaf (MgL); Sulfur in the stem (SS), in the floral bud (SB) and leaf (SL). Piracicaba-SP, 2012

\begin{tabular}{|c|c|c|c|c|c|c|}
\hline Ratios & $\mathrm{MgS}$ & $\mathrm{Mg} \mathrm{B}$ & $M g L$ & SS & SB & SL \\
\hline $2: 1$ & $1.33 \mathrm{~A}$ & $1.33 \mathrm{~A}$ & $2.40 \mathrm{~A}$ & $0.65 \mathrm{~A}$ & $0.70 \mathrm{~A}$ & $1.05^{\mathrm{a}}$ \\
\hline $1: 2$ & $1.18 \mathrm{~A}$ & $1.18 \mathrm{~A}$ & $2.42 \mathrm{~A}$ & $0.67 \mathrm{~A}$ & $0.83 \mathrm{~A}$ & $1.24^{\mathrm{a}}$ \\
\hline $1: 3$ & $1.08 \mathrm{~A}$ & $1.08 \mathrm{~A}$ & $2.60 \mathrm{~A}$ & $0.71 \mathrm{~A}$ & $0.98 \mathrm{~A}$ & $1.32^{\mathrm{a}}$ \\
\hline \multicolumn{7}{|c|}{ Factorial x Control } \\
\hline Factorial mean & $1.20 a$ & $1.20 a$ & $2.47 a$ & $0.68 a$ & $0.84 a$ & $1.20^{\mathrm{a}}$ \\
\hline Control mean & $0.73 b$ & $0.73 b$ & $1.75 \mathrm{~b}$ & $0.83 a$ & $0.79 a$ & $1.23^{\mathrm{a}}$ \\
\hline DMS & 0.27 & 0.27 & 0.29 & 0.23 & 0.27 & 0.29 \\
\hline
\end{tabular}
according to Tukey's test at 0.05 of probability

\section{Conclusions}

The highest levels of $\mathrm{N}, \mathrm{K}, \mathrm{P}, \mathrm{Ca}$ and $\mathrm{Mg}$ in plant tissues of rose crops are observed in the leaves. Nitrogen presented the highest content, followed by potassium;

TDR probe is a satisfactory tool in the management of fertirrigation, controlling the salinity of soil solution and the concentrations of nitrate (NO3) and potassium ( $\mathrm{K}+$ )

\section{References}

Burt, C., Connor, K., Ruehr, T. 1998. Fertigation. San Luis Obispo, California, EUA. 295 p.

Cadahía, C., Eymar, A., Sánchez, A., López-vela, D. 1998. Differences in nutrient uptake of four rose cultivars in sand culture. Acta Horticulturae 12: 335-341.

Casarini, E. 2004. Doses de N e K aplicados via fertirrigação na cultura da roseira (Rosa sp.) em ambiente protegido. 101f. (Tese de Doutorado) Escola Superior de Agricultura "Luiz de Queiroz", Piracicaba, Brasil.

Demiral, M.A. 2005. Comparative response of two olive (Olea europaea L.) cultivars to salinity. Turkish Journal of Agriculture and Forestry 29: $267-$ 274.

Dias, N.S., Duarte, S.N., Gheyi, H.R., Medeiros, J.F., Soares, T.M. 2005. Manejo da fertirrigação e salinidade do solo sob ambiente protegido usando utilizando-se extratores de solução do solo. Revista Brasileira de Engenharia Agrícola e Ambiental 9: 496-504.

Dutra, A.V. Nutrição e produção de rosas, cultivares "Vegas" e "Tineke". 2009. 94f. Tese (Doutorado em Solos e nutrição de plantas) Escola Superior de Agricultura "Luiz de Queiroz", Piracicaba, Brasil.

Eloi, M.W., Duarte, N.S., Soares, M.T. 2007. Níveis de salinidade e manejo da fertirrigação sobre características do tomateiro cultivado em ambiente protegido, Revista Brasileira Ciências
Agrárias 2: 83-89.

Feigin, A., Ginzburg, C., Gilead, S., Ackerman, A. 1986. Effect of $\mathrm{NH}_{4} / \mathrm{NO}_{3}$ ratio in nutrient solution on growth and yield of greenhouse roses. Acta Horticulturae 189: 127-135.

Gomes, E.W.F., Willadino, L., Martins, L.S.S., Camara, T.R. 2005. Variedades de bananeira tratadas com água salinizada em fase inicial de crescimento. Revista Brasileira de Engenharia Agrícola e Ambiental 9: 31-36.

Lima, C.J.G.S. 2013. Manejo da fertirrigação no cultivo de roseiras em ambiente protegido. 169f. (Tese de Doutorado) - Escola Superior de Agricultura "Luiz de Queiroz", Piracicaba, Brasil.

Lopes, L.N., Souza, C.F., Santoro, B.L. 2010. Utilização da TDR para monitoramento da solução de nitrato de potássio em Latossolo vermelho-amarelo. Engenharia Agrícola 30: 932947.

Malavolta, E., Vitti G.C., Oliveira, S.A. 1997. Avaliação do estado nutricional das plantas: princípios e aplicações. POTAFOS, Piracicaba, Brasil. 317p.

Medeiros, P.R.F., Duarte, S.N., Uyeda, C.A., Silva, E.F.F., Medeiros, J.F. 2011. Tolerância da cultura do tomate a salinidade em ambiente protegido. Revista Brasileira de Engenharia Agrícola e Ambiental 16: 51-55.

Medeiros, P.R.F.; Duarte, S.N.; Dias, C.T.S.; Silva, M.F.D. 2010. Tolerância do pepino à salinidade em ambiente protegido: efeitos sobre propriedades físico-químicas dos frutos. Irriga 15: 301-311.

Mills, H.A., Jones, J.B. 1996. Plant analysis handbook II. MicroMacro Publishing, Atenass, Grécia. 422 p.

Oliveira, E.C., Carvalho, J.A., Almeida, E.F.A., Rezende, F.C., Santos, B.G., Mimura, S.N. 2014. Evapotranspiração da roseira cultivada em ambiente protegido. Revista Brasileira de Engenharia Agrícola e Ambiental 18: 314-321. 
Rhoads, J.D., Raats, P.A.C., Prather, R.J. 1976. Effects of liquid-phase electrical conductivity, water content, and surface conductivity on bulk soil electrical conductivity. Soil Science Society of America Journal 40: 651-655.

Santana, G.S., Coelho, E.F., Silva, T.S.M., Ramos, M.M. 2007. Relação entre potássio na solução do solo, umidade e condutividade elétrica aparente do solo. Revista Brasileira de Engenharia Agrícola e Ambiental 11: 142-151.

Santos, M.R., Martinez, M.A., Matos, A.T., Oliveira, R.A., Zonta, J.H. 2009. Uso da reflectometria no domínio do tempo para avaliar a distribuição de nitrato em colunas de solo fertirrigados. Revista Ambiente e Água 4: 67- 81.

Souza, C.F., Folegatti, M.V., Matsura, E.E., Or, D. 2006. Calibração da reflectometria no domínio do tempo (TDR) para a estimativa da concentração da solução no solo. Engenharia Agrícola 26: 282-291.

Souza, C.F., Folegatti, M.V. 2010. Spatial and temporal characterization of water and solute distribution patterns. Scientia Agricola 67: 9-15.

Souza, C.F., Martins, R.B.T., Folegatti, M.V., Daroz, T.H.C., Silva, E.F.F. 2007. Uso da reflectometria no domínio do tempo (TDR) para avaliar a distribuição do nitrato no volume molhado do solo sob fertirrigação. Magistra 19:1 12-122.

Vetanovetz, R.P. 1996. Tissue analysis and interpretation. In: Reed, D.W. Water, media and nutrition for greenhouse crops. Ball Publishing, Batavia, EUA. p.197-219. 